This PDF is a selection from a published volume from the National Bureau of Economic Research

Volume Title: Frontiers in Health Policy Research, Volume 6

Volume Author/Editor: David M. Cutler and Alan M. Garber, editors

Volume Publisher: MIT Press

Volume ISBN: 0-262-03309-7

Volume URL: http://www.nber.org/books/cutl03-1

Conference Date: May 29, 2002

Publication Date: January 2003

Title: Smoking Cessation and Lifestyle Changes

Author: Gabriel Picone, Frank Sloan

URL: http://www.nber.org/chapters/c9866 


\section{Smoking Cessation and Lifestyle Changes}

Gabriel Picone, University of South Florida

Frank Sloan, Duke University and NBER

\section{Executive Summary}

We used the first five waves of the Health and Retirement Study (HRS) to study three distinct but possibly interrelated phenomena: smoking cessation, changes in alcohol consumption, and changes in weight. The HRS is well suited for our study because it contains smoking and drinking behavior measures; weight; detailed financial, demographic, and health data; and health conditions existing at baseline and those newly occurring. Men who quit smoking within two years before the interview reduced daily alcohol consumption by about 0.1 to 0.15 . Smoking cessation did not affect alcohol consumption for women. Unlike men, for whom there was no interaction between smoking cessation and problem drinking, female problem drinkers who quit smoking during the last two years reduced daily alcohol consumption by about 0.3 to 0.4 drinks per day on average, but the effect was only temporary. Quitting or starting heavy drinking had no effect on smoking cessation for either gender. Smoking cessation led to an increase in body mass index (BMI), both for men and for women. Furthermore, the effect increased with duration of smoking cessation. For men, BMI increased by 0.28 in the first two years after smoking cessation, but by almost 0.7 among male smokers who had quit more than two years previously. For females, the short-run effect of smoking cessation was larger, but the long-run effect was about the same as for men. A 0.7 increase in BMI is equivalent to about a five-pound increase in weight for a person who is 5 feet, 11 inches tall. Overall, our longitudinal analysis of HRS data shows that smoking cessation is negatively associated with alcohol consumption and positively associated with weight gain. The specific nature of the link between smoking cessation and alcohol consumption differs between the genders. 


\section{Introduction}

Several health behaviors affect longevity and quality of life: smoking, heavy use of alcohol, obesity, lack of exercise, stress, and other behaviors. While many studies have analyzed decisions to quit each one of these habits individually (e.g., Jones 1994, Douglas 1998, and Perreira and Sloan 2001), all of these habits jointly determine longevity and quality of life.

Smoking and high levels of alcohol consumption are positively correlated. Persons with drinking problems are two to three times more likely to smoke than are persons without such problems (Henningfield et al. 1990, Johnson and Jennison 1992, Rosengren et al. 1988). Smokers consume twice the amount of alcohol per capita as do nonsmokers (Carmody et al. 1985). As many as 80 percent of alcoholics smoke, and 30 percent of smokers are alcoholics (Miller and Gold 1998).

Weight and smoking are negatively correlated (Wee et al. 2001). Also, smokers, especially women, report that weight gain is a major impediment to smoking cessation (U.S. Department of Health and Human Services 1990, Pirie et al. 1991, Rigotti 1999). Smoking appears to have a weight-suppressant effect, and weight gain frequently occurs following smoking cessation (Klesges et al. 1991, Moffat and Owens 1991, Williamson et al. 1991). The observed relationship is fragile, however; it is sensitive to model specification (Wee et al. 2001).

Various behaviors, such as heavy drinking, might be complements to smoking, or they might be substitutes, such as overeating. To economists, two goods are complements or substitutes depending on whether the consumption level of one of the goods affects the marginal utility of consuming the other good. Consumption of two goods may be positively or negatively associated for reasons other than being complements or substitutes. For example, an increase in income may cause an increase in the consumption of a large number of goods. Or a health shock may affect the marginal utility of many goods, positively or negatively. But then a change in consumption of one good would not cause a change in the consumption of another. Smoking advertisements may be common in bars, not because cigarettes and alcoholic beverages are complements but because of a preference structure not observed by the researcher: that regular or heavy drinkers happen also to like cigarettes.

A complementary relationship implies that smoking cessation efforts may also reduce heavy drinking. Thus, alcohol treatment and smoking cessation programs may be partial substitutes. The evidence on this 
relationship is not clear. Edwards et al. (1997, p. 118) suggested that when problem drinkers stop drinking, they may compensate by smoking more; at least for problem drinkers, alcohol and cigarettes may be substitutes, not complements.

If smoking and overeating are substitutes, as some evidence suggests (see, for example, Flegal et al. 1995), and if many smokers, especially women, believe this suggestion to be true (U.S. Department of Health and Human Services 2001), concern about weight gain may be a barrier to smoking cessation. To the extent that such concerns are quantitatively important, it may be fruitful to incorporate successful methods for weight gain avoidance in interventions designed to promote smoking cessation. Quitting smoking may lead people to consume higher caloric meals. The 1990 report of the Surgeon General, Health Benefits of Smoking Cessation, concluded that, on average, quitting smoking leads to a weight gain of five pounds (U.S. Department of Health and Human Services 1990); nevertheless, the health benefits from smoking cessation far exceed the negative health effects associated with a weight gain.

Knowing substitution/complementary relationships is useful for public policy for at least three reasons. One is for gaining a more complete assessment of the full health effects of programs aimed at promoting cessation. For example, the relative risk of being obese on survival and disability seems to be far lower than the relative risk of smoking on these same outcomes (see, for example, Calle et al. 1999; Taylor and Ostbye 2001; Ostbye et al. 2002a and 2002b). But not accounting for the effect of smoking cessation on weight gain will lead to an overestimate of the health benefits of smoking cessation. On the other hand, if there are positive spillovers for alcohol use, the health benefits from smoking cessation would be underestimated.

Second, the results may be useful for the design of treatment interventions. Smoking cessation prior to formal treatment of alcoholism may improve subsequent drinking outcomes (Miller et al. 1983; McClure et al. 2002) and formal treatment of alcoholism may improve the success rates for smoking cessation programs (Burling et al. 1982).

A third use, related to the second, is for the design of specific information treatments to encourage reductions in each of these unhealthy habits. More truthful messages would incorporate information about the side effects of interventions. Also, to the extent that habits are complements or substitutes, it may be advantageous to design interventions that address more than one habit at once. 
Public policies, no matter how well intentioned, are subject to unintended consequences. For example, in the context of tobacco control, one purpose of imposing excise taxes is to reduce the consumption of a harmful substance. Faced with higher cigarette prices, however, smokers have adopted compensatory behaviors. Evans and Farrelly (1998) found that smokers respond to increases in price by reducing the number of cigarettes smoked; they also engage in several compensating behaviors like switching to brands that are higher in tar and nicotine. But unintended consequences can be favorable as well. In an analysis of smoking initiation, Dee (1999) found that laws that increased the minimum age for the consumption of alcohol also reduce smoking behaviors among teenagers.

In this study, we used the first five waves of the Health and Retirement Study (HRS) to study three distinct but possibly interrelated phenomena: smoking cessation, changes in alcohol consumption, and changes in weight. The HRS does not collect information on food consumption (other than total spending on food and spending on food away from home and home-delivered food), but it does ask about heavy exercise, which we analyze in addition to the body mass index (BMI). The BMI reflects weight relative to height. Weight gain reflects a combination of food intake and exercise, as well as factors that are exogenous to the individual (metabolism). Of these, only exercise is directly observed, although some factors determining the rate of metabolism are likely to be time-invariant and can be measured with fixed effects using panel data.

Having panel data is highly advantageous for empirical analysis of smoking cessation and concomitant behaviors. Smoking cessation is inherently longitudinal. With a panel, one can gauge the effects of a behavioral change, such as in smoking. Also, one can distinguish between exogenous events, such as health shocks, affecting several decisions simultaneously from changes in other behaviors due to a change in a behavior, such as in cigarette consumption. Using fixed effects, one can isolate the effects of time invariant factors that influence consumption of commodities from the effects of time-varying changes, such as in tobacco use. Finally, with a panel, one can assess the time path of responses of other decisions to a single decision, such as the decision to stop smoking.

Although panel data have many advantages over single and repeated cross-sectional data, results from panels may be subject to bias because of respondent attrition or nonresponse. Attrition bias can re- 
sult if the propensity to drop out is correlated with the outcome of interest. In our context, a health shock, such as a heart attack, may have caused an individual to quit smoking and to drink less, but at the same time it will increase his or her probability of death and dropping out of the sample. Our econometric strategy accounted for potential selectivity bias by estimating a probit model of surviving each wave and using Mills ratios as additional explanatory variables.

Section II of this chapter discusses conceptual issues underlying research on addictive behavior. Section III develops the econometric strategy. Sections IV to VI discuss data, the empirical specification, and the results, respectively. Section VII provides a conclusion for the chapter.

\section{Conceptual Issues}

A large body of literature has analyzed the consumption of addictive and harmful goods like cigarettes and alcohol. The consumption of these goods may seem irrational and outside the scope of economics, but today the most accepted economic framework to explain this kind of behavior assumes that individuals are rational and forward-looking, as formulated in Becker and Murphy's (1988) rational addiction model. In this framework, fully rational, forward-looking individuals choose whether or not to become addicted to a substance. A body of economic research finds empirical support for this model (see Chaloupka and Warner 2000). But as Gruber and Köszegi (2001) have argued, the empirical evidence is consistent with other models of addictive behavior in which people are forward-looking but time-inconsistent. ${ }^{1}$

In the original rational addiction model, smokers quit cold turkey because of exogenous shocks, such as from changes in the relative price of the good or health shocks. Goldbaum (2000) recently extended the rational addiction model to show that forward-looking rational addicts may quit gradually because, as the individual ages, he or she places a higher value on the health consequences of smoking. Using data from HRS, Sloan et al. (2003) also found that many smokers in late middle age quit gradually.

The theoretical literature on rational addiction models has been concerned only with the consumption of a single good, such as tobacco. Very few studies have investigated consumption of two addictive goods jointly. One exception is a recent paper by Arcidiacono et al. (2001), who used a structural model to explain decisions of male HRS 
respondents to smoke and engage in heavy drinking. Their framework allowed for a comparison between fully rational, forward-looking behavior as hypothesized in the rational addiction model with an alternative model in which people do not consider the future consequences of their present actions. On balance, they found, if anything, observed patterns of smoking and heavy drinking were more consistent with a myopic than with a fully rational model. Testing the rational addiction model and gauging the empirical importance of time inconsistency are beyond the scope of this study. Instead our goal is to analyze empirically changes in health lifestyles after an individual quits smoking.

\section{Econometric Strategy}

We estimate the following basic equation:

$$
\begin{aligned}
y_{i t}= & \delta_{1}^{y} q_{i t}^{1}+\delta_{2}^{y} q_{i t}^{2}+\delta_{3}^{y} p q_{i t}^{1}+\delta_{4}^{y} p q_{i t}^{2}+\beta_{1}^{y} H_{i t} \\
& +\beta_{2}^{y} X_{i t}+\beta_{5}^{y} d_{t}+\beta_{6}^{y} p d_{t}+\mu_{i}+\varepsilon_{i t}^{y}
\end{aligned}
$$

where $y$ is the dependent variable: the number of drinks per day, the $\mathrm{BMI}$, or whether the individual engages in heavy exercise (defined below), among other health habits. The variable $q^{1}$ is a binary that equals 1 if the individual quit smoking between periods $t$ and $t-1$ and $q^{2}$ equals 1 if the individual quit anytime before period $t-1$. The variable $p q^{1}$ is a binary that equals 1 if a problem drinker (defined below) quit smoking between periods $t$ and $t-1$ and $p q^{2}$ equals 1 if a problem drinker quits before period $t-1$. Interacting a time-invariant measure of problem drinking with $q_{1}$ and $q_{2}$ generates these binaries. Effects of smoking cessation may be different for this subgroup of individuals. The vector $H$ stands for health variables and accounts for health shocks that have simultaneously caused smoking cessation and lifestyle changes. Exogenous variables, including prices and income, are included in $X ; d_{t}$ is a set of time dummies; and $p d_{t}$ is a set of dummy variables obtained by interacting $d_{t}$ with problem drinking. The variable $p d_{t}$ accounts for plausible differential trends in lifestyle behavior between problem drinkers and non-problem drinkers. The individual fixed effect is $\mu_{i} ; \varepsilon$ is an independent and identically distributed error term.

Coefficients $\delta_{1}$ and $\delta_{2}$ correspond to changes in $y$ (e.g., drinking behavior) after the individual quit smoking as contrasted with those who did not quit. The first coefficient measures effects during the period 
that the individual quit smoking, and the second measures the change in future periods. Lifestyle changes may not be permanent. Coefficients $\delta_{3}$ and $\delta_{4}$ measure the additional effects for problem drinkers who quit smoking.

Because the same health shocks that affect the individual decision to quit smoking and change his or her lifestyle also plausibly increase the probability of death, attrition in our panel might not be random. Ignoring sample attrition will yield inconsistent parameter estimates if the sample continuation is correlated with the unobserved variables. ${ }^{2}$ To control for this potential bias, we followed a two-step procedure (see Ziliak and Kniesner 1998). In the first step, we estimated the probabilities of survival between any two waves using probit methods. We then used these estimates to construct the sample selection Mills ratio $\lambda_{t}$. In the second step, we estimated the following attrition-corrected first-differences model:

$$
\begin{aligned}
\Delta y_{i t}= & \delta_{1}^{y} \Delta q_{i t}^{1}+\delta_{2}^{y} \Delta q_{i t}^{2}+\delta_{3}^{y} \Delta p q_{i t}^{1}+\delta_{4}^{y} \Delta p q_{i t}^{2}+\beta_{1}^{y} \Delta H_{i t} \\
& +\beta_{2}^{y} \Delta X_{i t}+\beta_{5}^{y} \Delta d_{t}+\beta_{6}^{y} \Delta p d_{t}+\beta_{7}^{y} \lambda_{i t}+\Delta \varepsilon_{i t}^{y}
\end{aligned}
$$

This first-differences model allowed us to control for individual fixed effects and sample attrition using traditional regression methods.

We also analyzed the correlation between smoking cessation and lifestyle changes by assessing the effects of changes in heavy drinking on the probability of smoking cessation. Specifically, we estimated the following smoking cessation equation:

$q_{i t}^{*}=\gamma_{1} g h d_{i t}+\gamma_{2} s h d_{i t}+\gamma_{3} h d_{i}+X_{i t} \alpha_{1}+H_{i t} \alpha_{2}+d_{t} \alpha_{3}+\lambda_{i t} \alpha_{4}+\varepsilon_{i t}$

If $q_{i t}^{*}>0$, the individual quits smoking between periods $t$ and $t-1$. The variables $q h d_{i t}$ and $s h d_{i t}$ are binaries indicating whether the individual quit or started heavy drinking between periods $t$ and $t-1$. Because individuals who do not smoke cannot quit, we could not use firstdifferences, as in our previous model. Instead, we controlled for timeinvariant heavy-drinking dummy $h d_{i}$, which equals 1 if the individual was a heavy drinker in any wave. We estimated this equation as a linear probability model.

\section{Data}

We used data from the first five waves of the HRS, which was a survey conducted in 1992, 1994, 1996, 1998, and 2000. The original HRS sample 
consists of persons who were born between 1931 and 1941 (hence were age 51-61 in 1992) and their spouses, who could be of any age. ${ }^{3}$ Baseline interviews were conducted in respondents' homes, with subsequent interviews conducted by telephone. A response rate of approximately 80 percent was obtained in each year. At baseline, 12,652 persons $(7,608$ households) were sampled (Juster and Suzman 1995).

The HRS is well suited for our study because it contains measures of smoking and drinking behavior; weight; detailed financial, demographic, and health data; and health conditions existing at baseline and those newly occurring. Formats differed somewhat among the waves. For purposes of this study's empirical analysis, we limited the sample to persons between the ages of 51 and 61 at wave 1 . Because we were concerned with the effects of smoking cessation on other health habits, we also limited our sample to current smokers at wave 1 . A total of 2,664 male and female respondents were included in our sample at wave 1 . Because of death or attrition, however, by wave 5 , our sample included 1,875 individuals-a 30 percent attrition rate in eight years.

In our analysis of the determinants of smoking cessation, we further restricted our sample to individuals who were smokers at the wave immediately before the decision. For example, if an individual quit smoking in wave 2, the person was dropped from the sample. If he or she restarted smoking in wave 4 , however, he or she rejoined the sample.

\section{Empirical Specification}

\section{Dependent Variables}

Our main dependent variables were drinking behavior and BMI. We measured drinking behavior by the number of drinks a day that the person reported consuming on average. In waves 1 and 2, HRS asked respondents if they ever drink alcoholic beverages. Those who consumed any alcohol were asked if they usually consume less than one, one to two, three to four, or five or more drinks per day. In subsequent waves, the HRS asked the number of days a week the person drinks and how much, allowing us to determine how many drinks each person consumed on average. To compare alcohol consumption across waves, we did the following. First, we calculated the mean number of drinks for each respondent in waves 3 and 4 and assigned this number to the categories used in waves 1 and 2. Second, for individuals who 
reported consuming less than one drink daily, we assigned the value of 0.5 drinks per day. We assigned the value of 1.5 for one to two drinks per day, 3.5 for three to four, and 6 for five or more drinks per day. For men, we defined current heavy drinking as consuming three or more drinks daily, and, for women, it was defined as two or more drinks daily.

In each wave, the HRS asked the respondent a question about weight (height was asked at baseline). Responses to these questions were used to calculate the respondent's BMI at each wave. A person with a BMI above 30 is considered obese, and someone with a BMI of 25-29 is considered overweight.

In addition, we assessed variation in two other variables: heavy exercise and religiosity. As explained above, weight reflects food intake and exercise, but the HRS provides information only on the latter. An increase in religiosity may affect a person's consumption patterns, particularly alcohol use, but may also affect cigarette consumption. The HRS made a major change in question content between waves 2 and 3. Therefore, we limited our analysis of heavy exercise to waves 3-5. The HRS asked respondents whether they engaged in vigorous physical activity three or more times weekly. Included in such activity is both recreational activity, such as jogging, and activity related to work. The HRS did not ask about the duration of heavy exercise for the times that individuals participated in such activity. At each wave, the HRS asked respondents how important religion is to the individual. Possible responses were 1 , not too important; 2 , somewhat important; 3 , very important. We assessed this variable as a continuous variable.

Finally, in our analysis of the determinants of smoking cessation, the dependent variable was a binary variable indicating whether the individual had quit smoking between waves.

\section{Explanatory Variables}

Our main explanatory variables were a binary variable indicating whether the individual had quit smoking in the last two years, and another binary variable indicating whether the individual had quit smoking before the last two years. By making this distinction, we could assess if smoking cessation leads to temporary or more lasting changes in the other assessed behaviors.

We measured problem drinking with a binary variable based on the CAGE instrument for clinical assessment of alcohol disorders. The 
instrument asks four questions: Have you ever felt that you should cut down (C) on your drinking? Have people annoyed (A) you by criticizing your drinking? Have you ever felt bad or guilty $(G)$ about drinking? Have you ever had a drink first thing in the morning [eye opener (E)]? We set the binary variable for "problem drinker" to 1 if the respondent gave affirmative answers to two or more of these questions. The CAGE instrument has been found to be a valid indicator of alcohol problems (Fink et al. 2002; Hearne et al. 2002). It picks up extreme rather than early cases (Edwards et al. 1997, p. 197). The HRS asked the CAGE questions only at the baseline interview. The survey did not ask when the person had experienced problems with alcohol use. We interacted problem drinker with binary variables for smoking cessation to determine whether problem drinkers who quit smoking reduce alcohol consumption by more or less than persons without drinking problems.

Other explanatory variables included annual household income and the following life events occurring since the last interview (two years previously): loss of job due to retirement or to unemployment, divorce, and the death of a spouse. Decreases in income should lead to decreased consumption of alcohol and food if they are normal goods. Losing a job and / or a spouse may also lead an individual to increase his or her consumption of alcohol and food to the extent that this event is stressful.

We also controlled for several health shocks between waves (specified as binary variables) that may have affected the individual's drinking behavior and weight: hospitalization for any cause, cancer, stroke, lung problems, diabetes, and heart attack. Two sets of the disease variables were included as explanatory variables: binary variables for onset of the disease since the last HRS interview and for onset prior to the previous interview-that is, pre-existing illness at any time before the past two years. Health shocks may lead to decreased consumption of various substances and cause individuals to update subjective probabilities of achieving a particular age (Smith et al. 2001). Also, substances such as alcohol interact with certain medications. Patients undergoing chemotherapy for cancer often lose their appetite; diabetics are advised to limit their intake of certain foods and to exercise more frequently. In all of these cases, a third variable, the health shock, potentially affects the smoking of cigarettes and the consumption of alcoholic beverages and food. It is important to account for these shocks to allow us to isolate complementary or substitutive relationships. 
In the drinking behavior equations, we also included a binary variable indicating whether the individual lived in a state that enacted a reduced blood alcohol content (BAC) standard for driving under the influence of alcohol as well as a variable for the state-level beer tax, in cents, at the time of the interview and the tax two years before the interview date (Chriqui et al. 2002). Several states reduced the BAC from 10 to 8 percent during the observational period. ${ }^{4} \mathrm{~A}$ reduction in the maximum BAC for driving legally should decrease social drinking. In real terms, state beer taxes declined considerably between 1990 and 2000 (Wagenaar 2000). An increase in the alcohol tax is likely to increase the price and reduce consumption.

All of the models included individual fixed effects, time binary variables, and time binaries interacted with problem drinking. Time dummies were included to control for natural trends in the consumption of alcohol and weight through time. The time-problem drinking interaction was included to account for differential trends that may have existed for problem drinkers in the absence of smoking cessation. Individual fixed effects were included to control for time-invariant individual characteristics, such as unmeasured individual preferences and genes that may affect the smoking cessation decision, drinking behavior, and the person's weight.

Finally, we included a smoking ban index, the percentage of state tax on cigarettes at the time of the interview, and a two-year lagged cigarette tax as additional explanatory variables in our analysis of the determinants of smoking cessation. The smoking ban index was created as follows. First, we constructed eight binary variables indicating if, at the time of the interview, the state had implemented restrictions on cigarette smoking. Restrictions on smoking were in private worksites, restaurants, bars, health care facilities, government worksites, grocery stores, malls, and hotels. Second, we created a smoking ban index giving double weight to restrictions in bars and private worksites and assigning a weight of 1 to the other restrictions. ${ }^{5}$ A higher smoking ban index should increase the time and inconvenience of smoking and thus increase the likelihood of cessation.

There was appreciable between-state and within-state variation in cigarette taxes during our study period. Under various assumptions, increases in the price of cigarettes will lead some smokers to quit (Gruber and Köszegi 2001).

All of our specifications included a Mills ratio for survival between waves, obtained using probit equations. In this analysis, the sample 
was the number of individuals who were alive at the time of the interview, and the dependent variable was a binary indicating if the individuals were alive in the next interview. Explanatory variables in this analysis included the health variables described above, time-invariant demographic characteristics, and the self-assessed probability of living to age 75 . These variables were found to be good predictors of an individual's own mortality (Smith et al. 2001) and probably include genetic information about the individual not contained in the health measures. We did not control for attrition that was not due to death, but this source of attrition is likely to be controlled by the individual fixed effects (see Ziliak and Kniesner 1998).

\section{Results}

Alcohol consumption and smoking are positively correlated for both males and females (table 5.1). At wave 1, current male smokers consumed 1.2 drinks daily in contrast to males who had never smoked, who consumed half as much. Current female smokers consumed almost 0.6 drinks daily, while the mean for females who had never smoked was 0.3 . Heavy drinking was over three times more prevalent among current smokers than among those who had never smoked for both males and females. Current smokers had slightly lower BMIs than others. Males who had never smoked were more likely to have engaged in heavy exercise than current smokers. ${ }^{6}$ Differences for females by smoking status were small. In general, smokers were less religious than nonsmokers. Problem drinkers had higher levels of alcohol consumption and were much more likely to be heavy drinkers. In the remaining tables and figures, we limit the sample to persons who smoked at wave 1 .

As individuals age, they consume less alcohol. For males, the decline was from 1.2 at wave 1 to slightly less than 0.8 drinks daily by wave 5 (figure 5.1). For women, the decline was from slightly under 0.6 drinks to about 0.3 drinks daily. With the exception of the wave 4 to 5 rate, smoking cessation rates were higher for men than for women (figure 5.2). For all two-year time intervals and both genders, two-year smoking cessation rates varied between 10 and 20 percent.

Weight, on the other hand, did not appear to vary with age (table 5.2). Mean BMI was about 26 in all waves and for both genders. Common life events were the loss of a job and hospitalization within the past two years. By wave 5, about one-quarter of the sample had been 
Table 5.1

Means of explanatory variables by smoking status in wave $1^{a}$

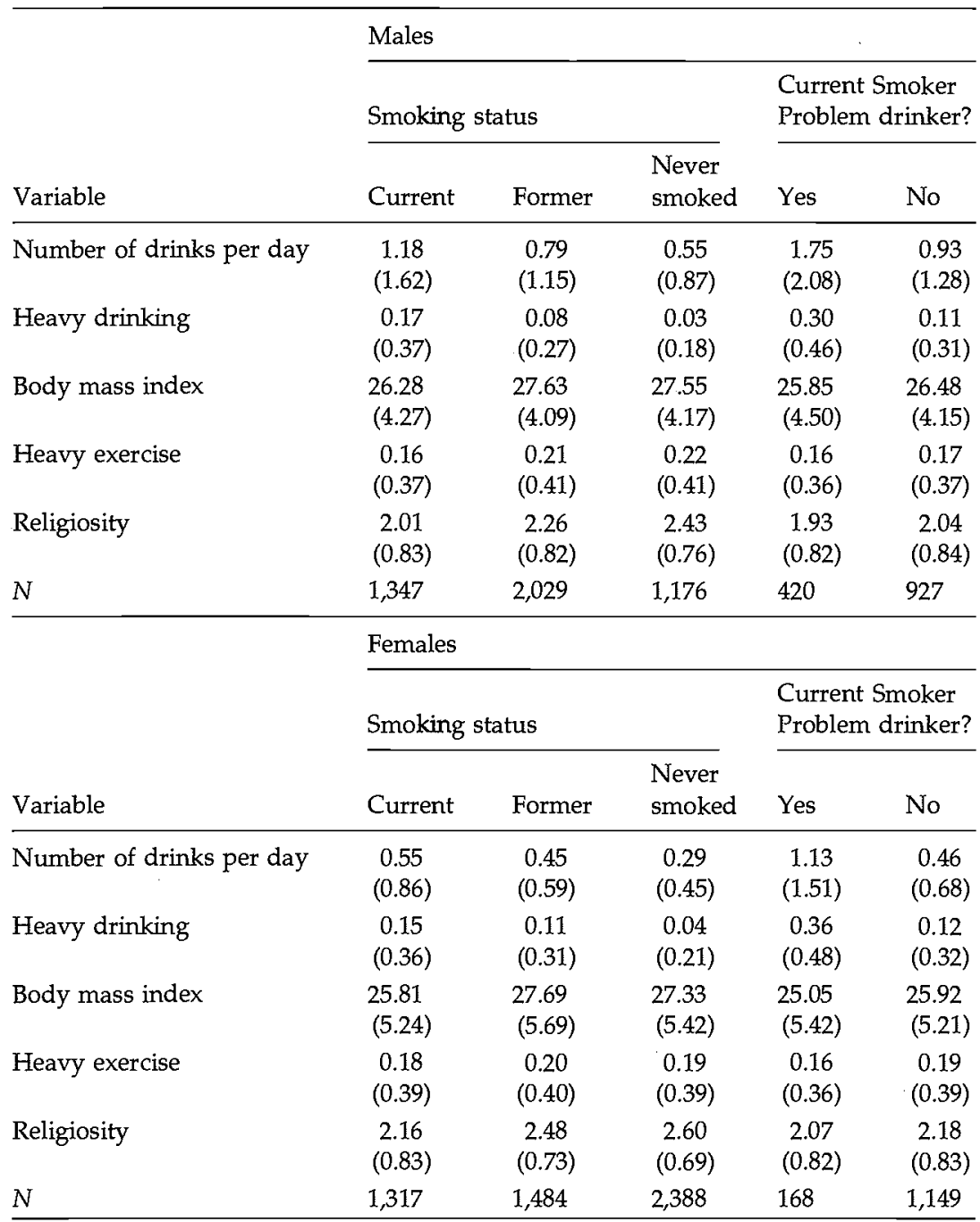

${ }^{a}$ Numbers in parentheses are standard deviations.

hospitalized within the previous two years. Health shocks were much more unlikely to have occurred in the two years before wave 5 than during the two years before wave 1 .

Men who quit smoking within two years before the interview reduced daily alcohol consumption by about 0.1 to 0.15 (table 5.3). The coefficient on quitting smoking within the past two years is statistically 


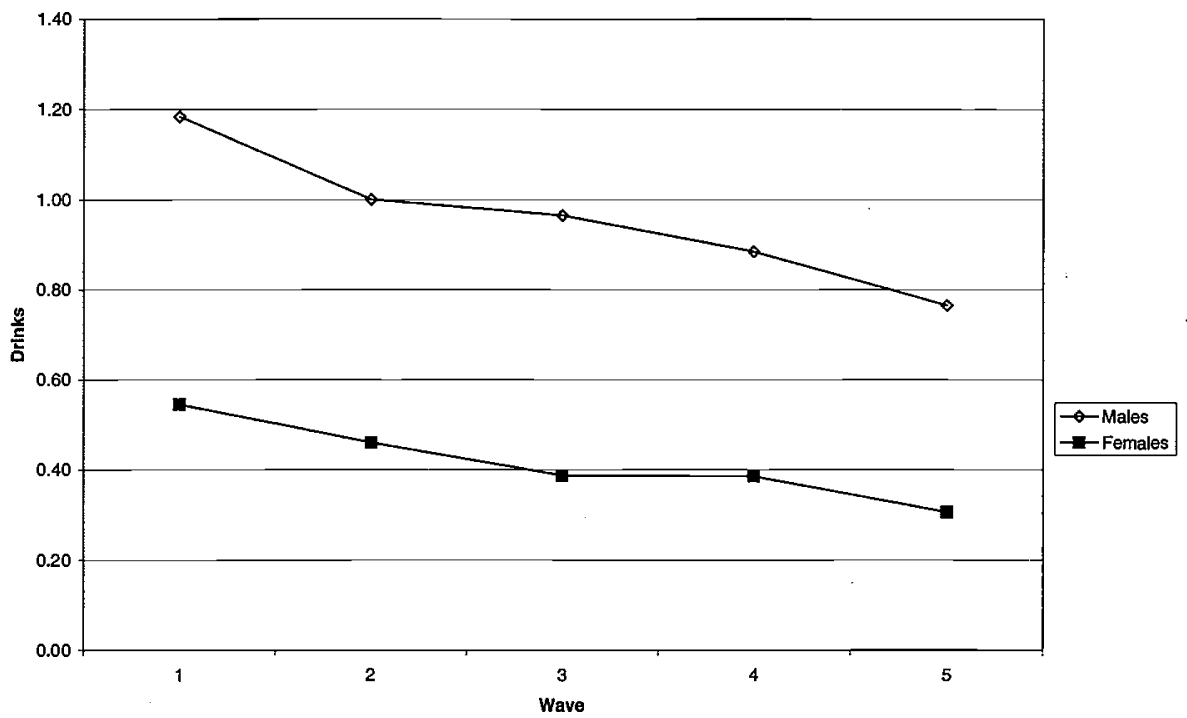

Figure 5.1

Drinks per day

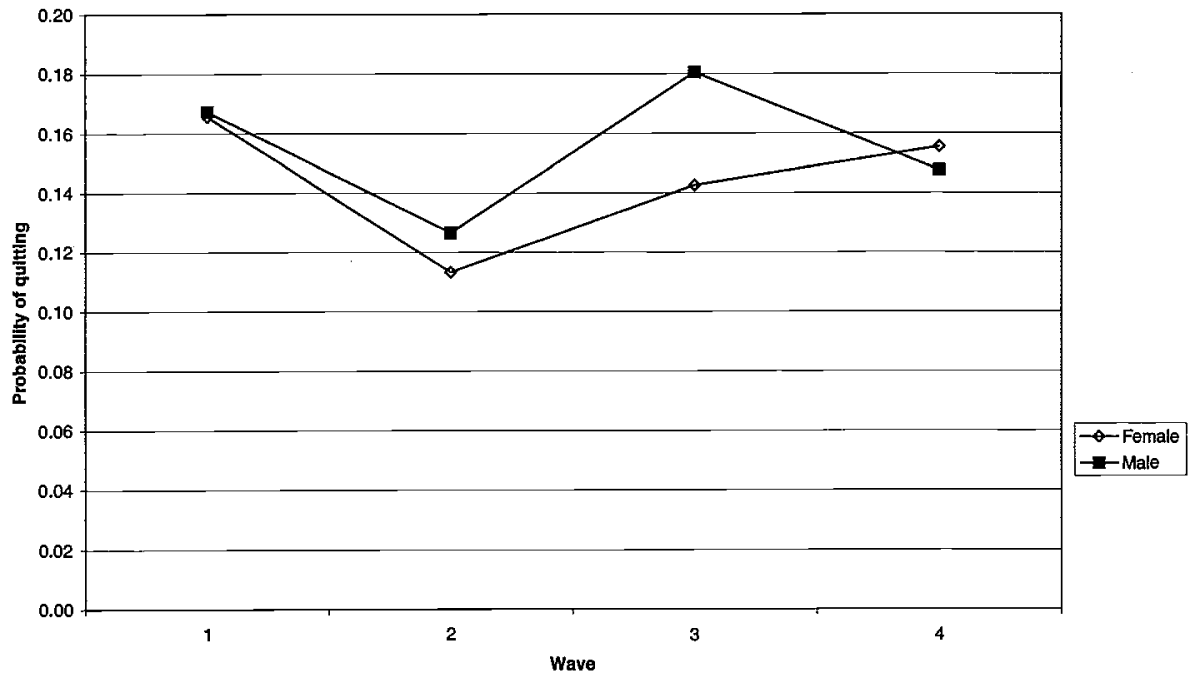

Figure 5.2

Smoking cessation hazard rates 


\section{Table 5.2}

Descriptive Statistics ${ }^{\mathrm{a}}$

\begin{tabular}{|c|c|c|c|c|}
\hline \multirow[b]{2}{*}{ Variable } & \multicolumn{2}{|l|}{ Males } & \multicolumn{2}{|l|}{ Females } \\
\hline & Wave 1 & Wave 5 & Wave 1 & Wave 5 \\
\hline Current smoker & $\begin{array}{c}1.00 \\
(0.00)\end{array}$ & $\begin{array}{l}0.65 \\
0.47)\end{array}$ & $\begin{array}{c}1.00 \\
(0.00)\end{array}$ & $\begin{array}{c}0.65 \\
(0.47)\end{array}$ \\
\hline $\begin{array}{l}\text { Smoking cessation during } \\
\text { (quit before last } 2 \text { years) }\end{array}$ & $(-)$ & $\begin{array}{c}0.10 \\
(0.30)\end{array}$ & $\stackrel{-}{(-)}$ & $\begin{array}{c}0.11 \\
(0.31)\end{array}$ \\
\hline $\begin{array}{l}\text { Lag former smoker } \\
\text { (quit before last } 2 \text { years) }\end{array}$ & $\begin{array}{l}- \\
(-)\end{array}$ & $\begin{array}{c}0.25 \\
(0.43)\end{array}$ & $\begin{array}{l}- \\
(-)\end{array}$ & $\begin{array}{c}0.24 \\
(0.43)\end{array}$ \\
\hline $\begin{array}{l}\text { Smoking cessation and } \\
\text { problem drinker }\end{array}$ & $\dot{-}(-)$ & $\begin{array}{c}0.03 \\
(0.17)\end{array}$ & $\begin{array}{l}- \\
(-)\end{array}$ & $\begin{array}{c}0.01 \\
(0.08)\end{array}$ \\
\hline $\begin{array}{l}\text { Lag former smoker and } \\
\text { problem drinker }\end{array}$ & $\begin{array}{l}- \\
(-)\end{array}$ & $\begin{array}{l}0.06 \\
(0.24)\end{array}$ & $\begin{array}{l}- \\
(-)\end{array}$ & $\begin{array}{c}0.02 \\
(0.14)\end{array}$ \\
\hline Body mass index & $\begin{array}{l}26.28 \\
(4.28)\end{array}$ & $\begin{array}{l}26.68 \\
(4.63)\end{array}$ & $\begin{array}{l}25.81 \\
(5.24)\end{array}$ & $\begin{array}{l}26.27 \\
(5.37)\end{array}$ \\
\hline Number of drinks per day & $\begin{array}{c}1.18 \\
(1.62)\end{array}$ & $\begin{array}{c}0.77 \\
(1.34)\end{array}$ & $\begin{array}{c}0.55 \\
(0.86)\end{array}$ & $\begin{array}{c}0.31 \\
(0.76)\end{array}$ \\
\hline Heavy drinking & $\begin{array}{c}0.17 \\
(0.37)\end{array}$ & $\begin{array}{c}0.09 \\
(0.29)\end{array}$ & $\begin{array}{c}0.13 \\
(0.34)\end{array}$ & $\begin{array}{c}0.11 \\
(0.31)\end{array}$ \\
\hline Heavy exercise ${ }^{b}$ & $\begin{array}{c}0.16 \\
(0.37)\end{array}$ & $\begin{array}{c}0.41 \\
(0.49)\end{array}$ & $\begin{array}{l}0.18 \\
(0.39)\end{array}$ & $\begin{array}{c}0.37 \\
(0.48)\end{array}$ \\
\hline Religiosity & $\begin{array}{c}2.01 \\
(0.83)\end{array}$ & $\begin{array}{c}2.32 \\
(0.76)\end{array}$ & $\begin{array}{c}2.16 \\
(0.83)\end{array}$ & $\begin{array}{c}2.61 \\
(0.60)\end{array}$ \\
\hline Family income (in $\$ 10,000$ s) & $\begin{array}{c}4.08 \\
(4.26)\end{array}$ & $\begin{array}{c}4.75 \\
(6.06)\end{array}$ & $\begin{array}{c}3.30 \\
(3.83)\end{array}$ & $\begin{array}{c}3.30 \\
(6.43)\end{array}$ \\
\hline Loss of job (last 2 years) & $\begin{array}{c}0.17 \\
(0.37)\end{array}$ & $\begin{array}{c}0.09 \\
(0.29)\end{array}$ & $\begin{array}{c}0.11 \\
(0.31)\end{array}$ & $\begin{array}{c}0.08 \\
(0.27)\end{array}$ \\
\hline Retired & $\begin{array}{c}0.10 \\
(0.30)\end{array}$ & $\begin{array}{c}0.44 \\
(0.50)\end{array}$ & $\begin{array}{c}0.07 \\
(0.25)\end{array}$ & $\begin{array}{c}0.32 \\
(0.47)\end{array}$ \\
\hline Unemployed & $\begin{array}{c}0.07 \\
(0.25)\end{array}$ & $\begin{array}{c}0.02 \\
(0.12)\end{array}$ & $\begin{array}{c}0.04 \\
(0.20)\end{array}$ & $\begin{array}{c}0.01 \\
(0.10)\end{array}$ \\
\hline $\begin{array}{l}\text { Widowed } \\
\text { (last } 2 \text { years) }\end{array}$ & $\stackrel{-}{(-)}$ & $\begin{array}{c}0.01 \\
(0.08)\end{array}$ & $\stackrel{-}{(-)}$ & $\begin{array}{c}0.02 \\
(0.12)\end{array}$ \\
\hline $\begin{array}{l}\text { Divorced } \\
\text { (last } 2 \text { years) }\end{array}$ & $\begin{array}{l}- \\
(-)\end{array}$ & $\begin{array}{c}0.01 \\
(0.08)\end{array}$ & $\begin{array}{l}- \\
(-)\end{array}$ & $\begin{array}{r}0.002 \\
(0.04)\end{array}$ \\
\hline $\begin{array}{l}\text { Hospitalization } \\
\text { (last } 2 \text { years) }\end{array}$ & $\begin{array}{c}0.12 \\
(0.32)\end{array}$ & $\begin{array}{c}0.26 \\
(0.44)\end{array}$ & $\begin{array}{c}0.10 \\
(0.30)\end{array}$ & $\begin{array}{c}0.24 \\
(0.43)\end{array}$ \\
\hline $\begin{array}{l}\text { Onset of cancer } \\
\text { (last } 2 \text { years) }\end{array}$ & $\begin{array}{c}0.01 \\
(0.11)\end{array}$ & $\begin{array}{c}0.03 \\
(0.18)\end{array}$ & $\begin{array}{c}0.01 \\
(0.12)\end{array}$ & $\begin{array}{c}0.03 \\
(0.18)\end{array}$ \\
\hline $\begin{array}{l}\text { Lag cancer } \\
\text { (before last } 2 \text { years) }\end{array}$ & $\begin{array}{c}0.02 \\
(0.14)\end{array}$ & $\begin{array}{c}0.09 \\
(0.29)\end{array}$ & $\begin{array}{c}0.07 \\
(0.25)\end{array}$ & $\begin{array}{c}0.12 \\
(0.33)\end{array}$ \\
\hline $\begin{array}{l}\text { Onset of stroke } \\
\text { (last } 2 \text { years) }\end{array}$ & $\begin{array}{c}0.01 \\
(0.09)\end{array}$ & $\begin{array}{c}0.03 \\
(0.18)\end{array}$ & $\begin{array}{c}0.01 \\
(0.08)\end{array}$ & $\begin{array}{c}0.02 \\
(0.14)\end{array}$ \\
\hline $\begin{array}{l}\text { Lag stroke } \\
\text { (before last } 2 \text { years) }\end{array}$ & $\begin{array}{c}0.03 \\
(0.17)\end{array}$ & $\begin{array}{c}0.06 \\
(0.24)\end{array}$ & $\begin{array}{c}0.02 \\
(0.14)\end{array}$ & $\begin{array}{c}0.06 \\
(0.23)\end{array}$ \\
\hline
\end{tabular}


Table 5.2

(continued) $^{\mathrm{a}}$

\begin{tabular}{|c|c|c|c|c|}
\hline \multirow[b]{2}{*}{ Variable } & \multicolumn{2}{|l|}{ Males } & \multicolumn{2}{|l|}{ Females } \\
\hline & Wave 1 & Wave 5 & Wave 1 & Wave 5 \\
\hline $\begin{array}{l}\text { Onset of diabetes } \\
\text { (last } 2 \text { years) }\end{array}$ & $\begin{array}{l}0.02 \\
(0.13)\end{array}$ & $\begin{array}{l}0.03 \\
(0.17)\end{array}$ & $\begin{array}{c}0.02 \\
(0.13)\end{array}$ & $\begin{array}{l}0.04 \\
(0.18)\end{array}$ \\
\hline $\begin{array}{l}\text { Lag diabetes } \\
\text { (before last } 2 \text { years) }\end{array}$ & $\begin{array}{l}0.09 \\
(0.28)\end{array}$ & $\begin{array}{l}0.16 \\
(0.37)\end{array}$ & $\begin{array}{l}0.07 \\
(0.25)\end{array}$ & $\begin{array}{c}0.14 \\
(0.35)\end{array}$ \\
\hline $\begin{array}{l}\text { Onset of heart attack } \\
\text { (last } 2 \text { years) }\end{array}$ & $\begin{array}{l}0.02 \\
(0.15)\end{array}$ & $\begin{array}{l}0.04 \\
(0.19)\end{array}$ & $\begin{array}{c}0.01 \\
(0.11)\end{array}$ & $\begin{array}{c}0.02 \\
(0.14)\end{array}$ \\
\hline $\begin{array}{l}\text { Lag heart attack } \\
\text { (before last } 2 \text { years) }\end{array}$ & $\begin{array}{c}0.07 \\
(0.25)\end{array}$ & $\begin{array}{c}0.16 \\
(0.37)\end{array}$ & $\begin{array}{c}0.03 \\
(0.17)\end{array}$ & $\begin{array}{c}0.09 \\
(0.29)\end{array}$ \\
\hline Lung problem & $\begin{array}{c}0.13 \\
(0.33)\end{array}$ & $\begin{array}{c}0.17 \\
(0.38)\end{array}$ & $\begin{array}{c}0.14 \\
(0.35)\end{array}$ & $\begin{array}{c}0.19 \\
(0.39)\end{array}$ \\
\hline Depression index & $\begin{array}{l}2.30 \\
(2.05)\end{array}$ & $\begin{array}{l}1.57 \\
(1.89)\end{array}$ & $\begin{array}{l}2.71 \\
(2.15)\end{array}$ & $\begin{array}{l}2.13 \\
(2.27)\end{array}$ \\
\hline Self-reported health & $\begin{array}{c}2.85 \\
(1.25)\end{array}$ & $\begin{array}{l}3.09 \\
(1.15)\end{array}$ & $\begin{array}{l}2.83 \\
(1.20)\end{array}$ & $\begin{array}{r}2.979 \\
(1.14)\end{array}$ \\
\hline Alcohol tax & $\begin{array}{l}2.96 \\
(2.14)\end{array}$ & $\begin{array}{l}2.61 \\
(1.90)\end{array}$ & $\begin{array}{l}2.81 \\
(2.07)\end{array}$ & $\begin{array}{l}2.53 \\
(1.89)\end{array}$ \\
\hline Blood alcohol content $0.08 \%$ & $\begin{array}{l}0.07 \\
(0.25)\end{array}$ & $\begin{array}{c}0.31 \\
(0.46)\end{array}$ & $\begin{array}{c}0.07 \\
(0.26)\end{array}$ & $\begin{array}{c}0.33 \\
(0.47)\end{array}$ \\
\hline Cigarette tax & $\begin{array}{l}26.43 \\
(11.29)\end{array}$ & $\begin{array}{l}42.86 \\
(27.04)\end{array}$ & $\begin{array}{l}26.27 \\
(11.48)\end{array}$ & $\begin{array}{l}43.52 \\
(27.99)\end{array}$ \\
\hline Smoking ban index & $\begin{array}{c}4.61 \\
(3.30)\end{array}$ & $\begin{array}{l}5.77 \\
(3.46)\end{array}$ & $\begin{array}{c}4.64 \\
(3.29)\end{array}$ & $\begin{array}{l}5.91 \\
(3.46)\end{array}$ \\
\hline$N$ & 1,347 & 900 & 1,317 & 975 \\
\hline$N$ died & & 231 & & 141 \\
\hline
\end{tabular}

${ }^{a}$ Numbers in parentheses are standard deviations.

${ }^{\mathrm{b}}$ The question for heavy exercise changed in wave 3 . In our analysis we used waves 3 to 5 for the analysis of heavy exercise.

significant, at better than the 10 percent level in regressions that do not contain covariates other than for smoking and drinking behavior [regression (1)]. With the health variables included, the coefficient remains negative but is no longer statistically significant, even at the 10 percent level. The effect on alcohol consumption is temporary and appears to be due to health shocks that affect drinking and smoking at the same time. Two health variables have statistically significant effects on alcohol consumption. Men who were hospitalized during the past two years reduced daily consumption by 0.2 on average. Depressed men drank slightly more. 
Smoking cessation did not affect the alcohol consumption of women. Unlike men, for whom there was no interaction between smoking cessation and problem drinking, problem drinkers who quit smoking during the last two years reduced daily alcohol consumption by about 0.3 to 0.4 drinks per day on average, but the effect was only temporary. Female problem drinkers who quit smoking earlier than the previous two years did not reduce daily alcohol consumption. For women, depression was also associated with slightly higher daily consumption rates. Diabetes reduced such consumption by almost 0.2 drinks daily.

Smoking cessation has no effect for men when the probability of heavy drinking is the dependent variable. Men who were hospitalized during the past two years had a 0.07 lower probability of engaging in heavy drinking. For women, the problem drinker-recent quitting interaction is statistically significant when heavy drinking is the dependent variable; like alcohol consumption, this effect applies to female but not male problem drinkers. Women who were depressed were more likely to be heavy drinkers.

Quitting or starting heavy drinking had no effect on smoking cessation for either gender (table 5.4). People who quit smoking before were more likely to quit again, thus demonstrating a pattern of repeated attempts at quitting prior to success. This pattern is evident, even though smoking was measured only at two-year intervals. Health shocks had a greater impact on smoking cessation than on alcohol consumption. Men who experienced a recent hospitalization, cancer, and / or heart attack were more likely to quit smoking. For women, these shocks also increased the probability of smoking cessation, but a stroke and / or the onset of diabetes also induced women to quit.

Smoking cessation led to an increase in BMI, for both men and women (table 5.5). Furthermore, the effect appears to increase with duration of smoking cessation. For men, with covariates included in the analysis, BMI increased by 0.28 in the first two years after smoking cessation, but by almost 0.7 among male smokers who quit more than two years previously. For females, the short-run effect of smoking cessation was larger, but the long-run effect was about the same as for men. A 0.7 increase in BMI is equivalent to about a five-pound increase in weight for a person who is 5 feet, 11 inches tall. ${ }^{7}$

For women, but not men, problem drinkers who quit smoking experienced a decrease in weight, but as with alcohol consumption, the effect was only temporary. For both genders, the weight gain is limited 


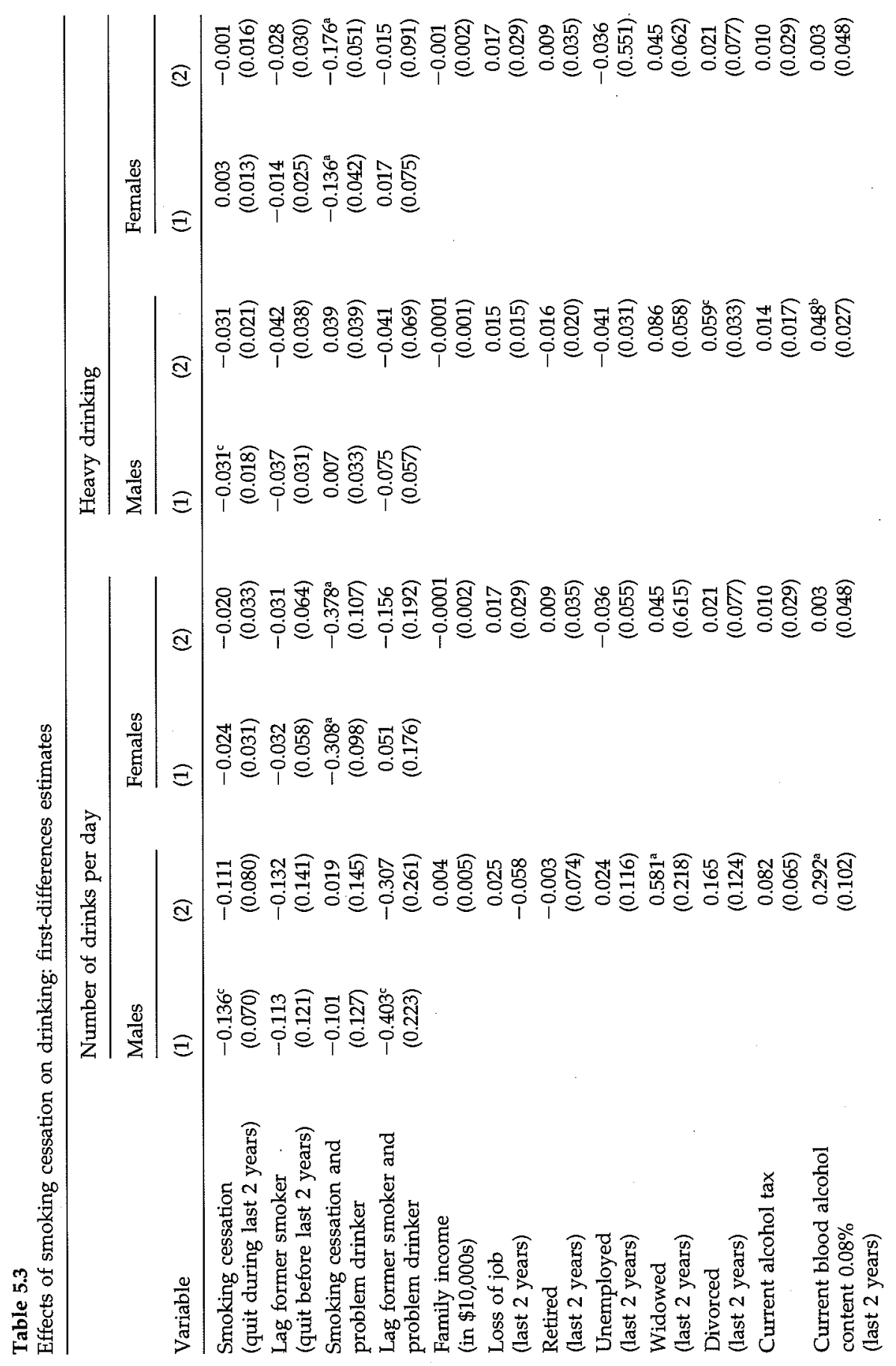




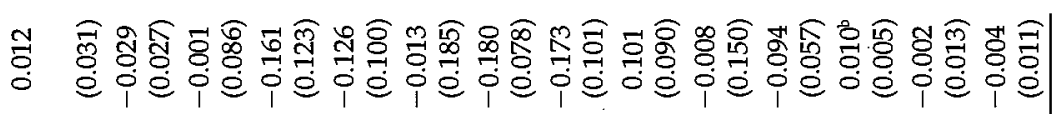

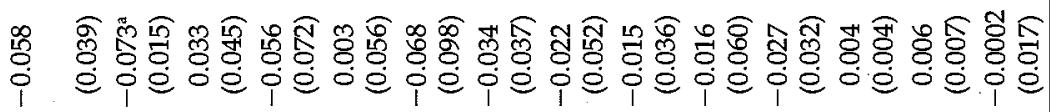

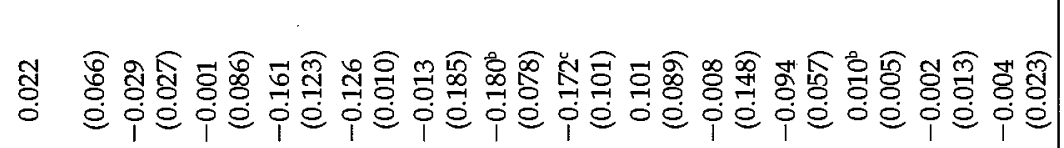

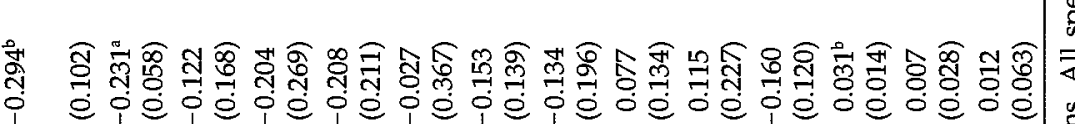
গ 
Table 5.4

Difference-in-difference linear probability estimates of changes in heavy drinking on smoking cessation

\begin{tabular}{|c|c|c|c|c|}
\hline \multirow[b]{2}{*}{ Variable } & \multicolumn{2}{|l|}{ Males } & \multicolumn{2}{|l|}{ Females } \\
\hline & (1) & (2) & (1) & (2) \\
\hline $\begin{array}{l}\text { Quit heavy drinking } \\
\text { (last } 2 \text { years) }\end{array}$ & $\begin{array}{l}0.060 \\
(0.040)\end{array}$ & $\begin{array}{c}0.038 \\
(0.046)\end{array}$ & $\begin{array}{c}-0.011 \\
(0.037)\end{array}$ & $\begin{array}{c}0.006 \\
(0.041)\end{array}$ \\
\hline $\begin{array}{l}\text { Start heavy drinking } \\
\text { (last } 2 \text { years) }\end{array}$ & $\begin{array}{c}-0.001 \\
(0.043)\end{array}$ & $\begin{array}{c}0.001 \\
(0.050)\end{array}$ & $\begin{array}{c}-0.016 \\
(0.074)\end{array}$ & $\begin{array}{r}-0.023 \\
(0.046)\end{array}$ \\
\hline Quit heavy drinking and problem drinker & $\begin{array}{c}0.003 \\
(0.059)\end{array}$ & $\begin{array}{r}-0.001 \\
(0.070)\end{array}$ & $\begin{array}{c}0.109 \\
(0.074)\end{array}$ & $\begin{array}{r}0.182^{\mathrm{b}} \\
(0.085)\end{array}$ \\
\hline Start heavy drinking and problem drinker & $\begin{array}{c}0.006 \\
(0.068)\end{array}$ & $\begin{array}{c}0.012 \\
(0.082)\end{array}$ & $\begin{array}{c}-0.081 \\
(0.088)\end{array}$ & $\begin{array}{c}-0.032 \\
(0.098)\end{array}$ \\
\hline Quit smoking before last 2 years & & $\begin{array}{r}0.093^{b} \\
(0.041)\end{array}$ & & $\begin{array}{r}0.185^{\mathrm{a}} \\
(0.041)\end{array}$ \\
\hline Family income (in $\$ 10,000$ s) & & $\begin{array}{c}0.003 \\
(0.002)\end{array}$ & & $\begin{array}{c}0.001 \\
(0.001)\end{array}$ \\
\hline $\begin{array}{l}\text { Loss of job } \\
\text { (last } 2 \text { years) }\end{array}$ & & $\begin{array}{r}0.048^{b} \\
(0.023)\end{array}$ & & $\begin{array}{c}0.014 \\
(0.023)\end{array}$ \\
\hline $\begin{array}{l}\text { Widowed } \\
\text { (last } 2 \text { years) }\end{array}$ & & $\begin{array}{c}0.072 \\
(0.093)\end{array}$ & & $\begin{array}{l}-0.016 \\
(0.050)\end{array}$ \\
\hline $\begin{array}{l}\text { Divorced } \\
\text { (last } 2 \text { years) }\end{array}$ & & $\begin{array}{r}-0.004 \\
(0.050)\end{array}$ & & $\begin{array}{r}-0.058 \\
(0.063)\end{array}$ \\
\hline $\begin{array}{l}\text { Current cigarette tax } \\
\text { (last } 2 \text { years) }\end{array}$ & & $\begin{array}{r}-0.0001 \\
(0.001)\end{array}$ & & $\begin{array}{r}0.0001 \\
(0.001)\end{array}$ \\
\hline $\begin{array}{l}\text { Lag cigarette tax } \\
\text { (before last } 2 \text { years) }\end{array}$ & & $\begin{array}{c}0.001 \\
(0.001)\end{array}$ & & $\begin{array}{r}0.0001 \\
(0.001)\end{array}$ \\
\hline $\begin{array}{l}\text { Current smoking ban index } \\
\text { (last } 2 \text { years) }\end{array}$ & & $\begin{array}{c}0.004 \\
(0.004)\end{array}$ & & $\begin{array}{r}0.007^{c} \\
(0.004)\end{array}$ \\
\hline $\begin{array}{l}\text { Lag smoking ban index } \\
\text { (before last } 2 \text { years) }\end{array}$ & & $\begin{array}{l}-0.006 \\
(0.005)\end{array}$ & & $\begin{array}{r}-0.006 \\
(0.004)\end{array}$ \\
\hline $\begin{array}{l}\text { Hospitalization } \\
\text { (last } 2 \text { years) }\end{array}$ & & $\begin{array}{r}0.096^{\mathrm{a}} \\
(0.019)\end{array}$ & & $\begin{array}{r}0.067^{\mathrm{a}} \\
(0.019)\end{array}$ \\
\hline $\begin{array}{l}\text { Onset of cancer } \\
\text { (last } 2 \text { years) }\end{array}$ & & $\begin{array}{r}0.098^{b} \\
(0.050)\end{array}$ & & $\begin{array}{r}0.195^{\mathrm{a}} \\
(0.051)\end{array}$ \\
\hline $\begin{array}{l}\text { Lag cancer } \\
\text { (before last } 2 \text { years) }\end{array}$ & & $\begin{array}{r}-0.063 \\
(0.053)\end{array}$ & & $\begin{array}{r}-0.014 \\
(0.037)\end{array}$ \\
\hline $\begin{array}{l}\text { Onset of stroke } \\
\text { (last } 2 \text { years) }\end{array}$ & & $\begin{array}{c}0.077 \\
(0.067)\end{array}$ & & $\begin{array}{r}0.267^{\mathrm{a}} \\
(0.068)\end{array}$ \\
\hline $\begin{array}{l}\text { Lag stroke } \\
\text { (before last } 2 \text { years) }\end{array}$ & & $\begin{array}{c}0.015 \\
(0.046)\end{array}$ & & $\begin{array}{c}0.028 \\
(0.060)\end{array}$ \\
\hline $\begin{array}{l}\text { Onset of diabetes } \\
\text { (last } 2 \text { years) }\end{array}$ & & $\begin{array}{c}0.042 \\
(0.045)\end{array}$ & & $\begin{array}{r}0.088^{c} \\
(0.053)\end{array}$ \\
\hline $\begin{array}{l}\text { Lag diabetes } \\
\text { (before last } 2 \text { years) }\end{array}$ & & $\begin{array}{c}0.005 \\
(0.029)\end{array}$ & & $\begin{array}{c}0.022 \\
(0.031)\end{array}$ \\
\hline
\end{tabular}


Table 5.4

(continued)

\begin{tabular}{|c|c|c|c|c|}
\hline \multirow[b]{2}{*}{ Variable } & \multicolumn{2}{|c|}{ Males } & \multicolumn{2}{|c|}{ Females } \\
\hline & (1) & (2) & (1) & (2) \\
\hline $\begin{array}{l}\text { Onset of heart attack } \\
\text { (last } 2 \text { years) }\end{array}$ & & $\begin{array}{c}0.224^{\mathrm{a}} \\
(0.040)\end{array}$ & & $\begin{array}{r}0.198^{\mathrm{a}} \\
(0.057)\end{array}$ \\
\hline $\begin{array}{l}\text { Lag heart attack } \\
\text { (before last } 2 \text { years) }\end{array}$ & & $\begin{array}{l}-0.001 \\
(0.030)\end{array}$ & & $\begin{array}{r}-0.013 \\
(0.041)\end{array}$ \\
\hline Lung problem & & $\begin{array}{c}-0.006 \\
(0.022)\end{array}$ & & $\begin{array}{c}0.010 \\
(0.020)\end{array}$ \\
\hline Depression index & & $\begin{array}{c}-0.004 \\
(0.004)\end{array}$ & & $\begin{array}{c}0.001 \\
(0.003)\end{array}$ \\
\hline Self-reported health & & $\begin{array}{r}-0.013 \\
(0.009)\end{array}$ & & $\begin{array}{c}0.003 \\
(0.008)\end{array}$ \\
\hline Mills ratio & & $\begin{array}{c}0.003 \\
(0.023)\end{array}$ & & $\begin{array}{c}0.018 \\
(0.016) \\
\end{array}$ \\
\hline
\end{tabular}

All specifications include time and drinking behavior fixed effects. Numbers in parentheses are standard deviations.

aSignificant at the $1 \%$ level two-tail test.

bSignificant at the $5 \%$ level two-tail test.

'Significant at the $10 \%$ level two-tail test.

to people who quit smoking and who are not obese (BMI over 30). For obese persons, especially women, smoking cessation led to weight loss.

To determine whether smoking cessation was associated with an overall lifestyle change, we studied the impact of smoking cessation and other factors on heavy exercise and religiosity (table 5.6). Heavy exercise for men did not change following smoking cessation. For women, smoking cessation led to an increase in the probability of engaging in heavy exercise. The long-run impact was about twice the short-run impact.

In the analysis of religiosity, only one coefficient is statistically significant at even the 10 percent level. Without covariates, female smokers who quit over two years before the interview became less religious. Thus, based on these two indicators, we found no evidence of a general lifestyle change, except for women, who did exercise more.

The statistically insignificant coefficients on the Mills ratio imply that sample attrition was not an important source of bias. Results tend to be similar between specifications that account for the Mills ratio and those that do not. 
Table 5.5

Effects of smoking cessation on weight: first-differences estimates

\begin{tabular}{lccccc}
\hline & \multicolumn{3}{l}{ Males } & & \multicolumn{2}{l}{ Females } \\
\cline { 2 - 3 } \cline { 5 - 6 } Variable & $(1)$ & & & $(1)$ & $(2)$ \\
\hline Smoking cessation & $0.340^{\mathrm{a}}$ & $0.280^{\mathrm{a}}$ & & $0.391^{\mathrm{a}}$ & $0.465^{\mathrm{a}}$ \\
(quit during last 2 years) & $(0.092)$ & $(0.106)$ & & $(0.097)$ & $(0.108)$ \\
Lag former smoker & $0.592^{\mathrm{a}}$ & $0.693^{\mathrm{a}}$ & & $0.612^{\mathrm{a}}$ & $0.737^{\mathrm{a}}$ \\
(quit before last 2 years) & $(0.160)$ & $(0.189)$ & & $(0.173)$ & $(0.200)$ \\
Smoking cessation and & 0.051 & 0.133 & & $-0.622^{\mathrm{b}}$ & $-0.870^{\mathrm{a}}$ \\
problem drinker & $(0.162)$ & $(0.168)$ & & $(0.283)$ & $(0.325)$ \\
Lag former smoker and & -0.025 & -0.068 & & $-1.031^{\mathrm{b}}$ & $-1.529^{\mathrm{b}}$ \\
problem drinker & $(0.278)$ & $(0.326)$ & & $(0.510)$ & $(0.602)$ \\
Smoking cessation and & -0.083 & 0.016 & & 0.213 & -0.252 \\
obese & $(0.196)$ & $(0.219)$ & & $(0.202)$ & $(0.234)$ \\
Lag former smoker and & $-0.661^{\mathrm{b}}$ & -0.456 & & -0.173 & $-0.855^{\mathrm{b}}$ \\
obese & $(0.315)$ & $(0.350)$ & & $(0.357)$ & $(0.421)$ \\
Mills ratio & & 0.043 & & $0.071^{\mathrm{a}}$ \\
& & $(0.026)$ & & $(0.023)$ \\
\hline
\end{tabular}

Regressions in columns marked (1) also include time fixed effects. Regressions in columns marked (2) also include income, changes in employment status, changes in marital status, hospitalization, onset of cancer, lag cancer, onset of stroke, lag stroke, onset of diabetes, lag diabetes, onset of heart attack, lag heart attack, lung problems, depression index, self-reported health, alcohol tax, blood alcohol content $0.08 \%$, and time fixed effects. Numbers in parentheses are standard deviations.

aSignificant at the $1 \%$ level two-tail test.

bSignificant at the $5 \%$ level two-tail test.

\section{Discussion and Conclusions}

A large body of epidemiological literature documents the complementarity of bad health habits (Taylor and Taylor 1984, Kandel 1975). For example, current smokers drink twice as much alcohol compared to nonsmokers (Carmody et al. 1985); 85 percent of current alcoholics smoke daily (DiFranza and Guerrera 1990). The reasons for these correlations are not well understood; they could be due to unmeasured individual preferences or because these goods have reinforcing effects (increased consumption of good A increases preferences for good B). An important health policy question is, Do policies designed to encourage the cessation of a bad habit have spillovers to other bad habits?

The major conclusion of The Health Benefits of Smoking Cessation: A Report of the Surgeon General (U.S. Department of Health and Human Services 1990) was that smoking cessation has major and immediate 
Table 5.6

Effects of smoking cessation on heavy exercise and religiosity: first-differences estimates

\begin{tabular}{lccccc}
\hline & \multicolumn{3}{l}{ Heavy exercise } & & \\
\cline { 2 - 3 } \cline { 5 - 6 } & \multicolumn{2}{l}{ Males } & & Females & \\
\cline { 2 - 3 } \cline { 5 - 6 } Variable & $(1)$ & & & $(1)$ & $(2)$ \\
\hline Smoking cessation & -0.057 & -0.068 & & $0.070^{\mathrm{a}}$ & $0.078^{\mathrm{a}}$ \\
(quit during last 2 years) & $(0.040)$ & $(0.052)$ & & $(0.036)$ & $(0.044)$ \\
Lag former smoker & -0.005 & 0.030 & & $0.118^{\mathrm{a}}$ & $0.142^{\mathrm{a}}$ \\
(quit before last 2 years) & $(0.067)$ & $(0.091)$ & & $(0.062)$ & $(0.077)$ \\
Smoking cessation and & 0.082 & 0.038 & & -0.147 & -0.034 \\
problem drinker & $(0.075)$ & $(0.099)$ & & $(0.135)$ & $(0.175)$ \\
Lag former smoker and & 0.085 & -0.089 & & -0.241 & -0.008 \\
problem drinker & $(0.123)$ & $(0.165)$ & & $(0.224)$ & $(0.285)$ \\
Mills ratio & & 0.018 & & 0.010 \\
& & $(0.044)$ & & $(0.039)$ \\
\hline
\end{tabular}

Importance of Religion

\begin{tabular}{|c|c|c|c|c|}
\hline \multirow[b]{2}{*}{ Variable } & \multicolumn{2}{|l|}{ Males } & \multicolumn{2}{|l|}{ Females } \\
\hline & (1) & $(2)$ & (1) & (2) \\
\hline $\begin{array}{l}\text { Smoking cessation } \\
\text { (quit during last } 2 \text { years) }\end{array}$ & $\begin{array}{c}0.002 \\
(0.031)\end{array}$ & $\begin{array}{r}-0.036 \\
(0.036)\end{array}$ & $\begin{array}{r}-0.011 \\
(0.025)\end{array}$ & $\begin{array}{r}-0.002 \\
(0.027)\end{array}$ \\
\hline $\begin{array}{l}\text { Lag former smoker } \\
\text { (quit before last } 2 \text { years) }\end{array}$ & $\begin{array}{r}-0.050 \\
(0.052)\end{array}$ & $\begin{array}{r}-0.020 \\
(0.002)\end{array}$ & $\begin{array}{r}-0.072^{\mathrm{a}} \\
(0.043)\end{array}$ & $\begin{array}{r}-0.063 \\
(0.049)\end{array}$ \\
\hline $\begin{array}{l}\text { Smoking cessation and } \\
\text { problem drinker }\end{array}$ & $\begin{array}{l}-0.015 \\
(0.061)\end{array}$ & $\begin{array}{c}0.002 \\
(0.072)\end{array}$ & $\begin{array}{c}0.024 \\
(0.082)\end{array}$ & $\begin{array}{c}0.054 \\
(0.092)\end{array}$ \\
\hline $\begin{array}{l}\text { Lag former smoker and } \\
\text { problem drinker }\end{array}$ & $\begin{array}{c}0.029 \\
(0.010)\end{array}$ & $\begin{array}{c}-0.078 \\
(0.120)\end{array}$ & $\begin{array}{c}-0.119 \\
(0.143)\end{array}$ & $\begin{array}{r}-0.019 \\
(0.160)\end{array}$ \\
\hline Mills ratio & & $\begin{array}{c}-0.001 \\
(0.010)\end{array}$ & & $\begin{array}{c}0.007 \\
(0.020)\end{array}$ \\
\hline
\end{tabular}

Regressions in columns marked (1) also include time fixed effects. Regressions in columns marked (2) also include income, changes in employment status, changes in marital status, hospitalization, onset of cancer, lag cancer, onset of stroke, lag stroke, onset of diabetes, lag diabetes, onset of heart attack, lag heart attack, lung problems, depression index, self-reported health, alcohol tax, blood alcohol content $0.08 \%$, and time fixed effects. Numbers in parentheses are standard deviations.

aSignificant at the $10 \%$ level two-tail test.

health benefits for persons of all ages. The report also acknowledged that short-term consequences of smoking cessation include anxiety, irritability, difficulty concentrating, and increased appetite. With the exception of increased appetite, these effects disappear in the long run. Increased appetite leads to an average 5-pound (2.3-kilogram) weight 
gain. In the short run, however, the psychological stress caused by smoking cessation may lead to increased alcohol consumption.

Using longitudinal data from the HRS, our analysis shows that smoking cessation is negatively correlated with alcohol consumption and positively correlated with weight gain. The specific nature of the link between smoking cessation and alcohol consumption differs between genders. These conclusions were not altered after we accounted for the endogeneity of smoking cessation. The negative association between smoking cessation and alcohol consumption can be seen as evidence of a change in lifestyle associated with quitting smoking. The mechanisms of the weight gain associated with quitting are not fully understood (U.S. Department of Health and Human Services 2001). Fortunately, the effect appears to be limited to persons who were not obese prior to smoking cessation. These results suggest that policies that encourage smoking cessation may have unintended positive externalities in terms of reduced alcohol consumption, and the negative impact on weight gain is limited.

An alternative to intervening is just to wait until the smoker or heavy drinker experiences an adverse health event. Many addicts quit under such circumstances. Of course, such adverse health events are costly in terms of added expense to public programs and to the families of severely ill smokers. It would seem desirable to avoid such shocks by encouraging people to quit before the health shocks occur. In our analysis, adverse health events lead to quitting, especially for smoking. Our results for the effects of health shocks on smoking cessation are consistent with findings from other databases (e.g., Clark and Etilé 2002, using data from the British Household Panel Survey).

An econometric caveat is that we may not have completely controlled for health shocks that jointly affected drinking, body mass index, and smoking cessation. With incomplete adjustment, smoking cessation may be correlated with the error terms, causing our estimated effects of smoking cessation to be biased. We did not include lagged and forward levels of alcohol consumption, as a rational addiction model requires. In an extension to this study, we are estimating a more structural model that includes lagged values of alcohol consumption and allows for the endogeneity of the smoking cessation binaries using the generalized methods of moments developed by Arellano and Bond (1991). Preliminary results indicate, however, that conclusions of this study in this paper are not altered. 


\section{Notes}

This study was supported in part by a grant from the National Institute on Alcoholism and Alcohol Abuse (NIAAA), "Determinants and Cost of Alcohol Abuse Among the Elderly" (R01-AA12162) to Duke University. We would like to thank Alex Wagenaar for making his data on alcohol policies available to us and we would also like to thank participants at the sixth NBER Frontiers in Health Policy Research Conference (Bethesda, Md., June 2002) for helpful comments.

1. Intuitively, time inconsistency means the following. As a shopper, I may not buy peach ice cream, knowing that at around 10 P.M., I will raid the icebox if the ice cream is there. Thus, there is the rational self who avoids the purchase and the more shortsighted self who figures that a little ice cream won't do that much harm and tastes so good. In the context of smoking and/or heavy drinking, a person may know that these behaviors are bad, but at a particular instance, taking that extra puff or extra drink is enjoyable and in itself does not seem to have much of an adverse impact on health. The above example assumes that the individual knows he or she has a self-control problem. In another variant of time inconsistency, the individual lacks self-control but does not know it.

2. See Moffit et al. (1999) for a discussion of the literature on panel attrition.

3. A younger age cohort was added in 1998. We did not include these individuals in our analysis.

4. Dee (1999) provides a summary of the implementation of these laws and its effects on saving lives.

5. Data on smoking restrictions were obtained from the U.S. Centers for Disease Control web site at http://www.cdc.gov.

6. The measure used here for heavy exercise comes from wave 1 . The definition differs somewhat from the definition used in waves 3-5 and in our multivariate analysis.

7. This figure appears to be at the low end of the literature. See U.S. Department of Health and Human Services (2001), pp. 15, 309-310.

\section{References}

Arcidiacono, P., H. Sieg, and F. Sloan (2001). "Living Rationally Under the Volcano? An Empirical Analysis of Heavy Drinking and Smoking," NBER working paper no. 8602.

Arellano, M., and S. Bond (1991). "Some Test of Specification for Panel Data: Monte Carlo Evidence and Application to Employment Equations," Review of Economic Studies, 58: 277-297.

Becker, G., and K. Murphy (1988). "A Theory of Rational Addiction," Journal of Political Economics 96(4):675-700.

Burling, T. A., M. L. Stitzer, G. E. Bigelow, and N. W. Russ (1982). "Techniques Used by Smokers During Contingency Motivated Smoking Reduction," Addictive Behavior, $7(4): 397-401$. 
Calle, E. E., M. J. Thun, J. M. Petrelli, et al. (1999). "Body-Mass Index and Mortality in a Prospective Cohort of U.S. Adults," New England Journal of Medicine, 341(15):1097-1105.

Carmody, T. P., C. Brischetto, J. Matarazzo, et al. (1985). "Concurrent Use of Cigarettes, Alcohol, and Coffee in Healthy Community-Living Men and Women," Health Psychology, $4(4): 323-335$.

Chaloupka, F., and K. Warner (2000). "The Economics of Smoking," Handbook of Health Economics, 1539-1627.

Chriqui, J. F., R. L. Pacula, and D. C. McBride (2002). Illicit drug policies: Selected laws from 50 states. Berrien Springs, Mich.: Andrews University.

Clark, A., and F. Etile (2002). "Do Health Changes Affect Smoking? Evidence from British Panel Data," Journal of Health Economics, 21(4):533-562.

Dee, T. (1999). "The Complementarity of Teen Smoking and Drinking," Journal of Health Economics, 18:769-793.

DiFranza, J. R., and M. P. Guerrera (1990). "Alcoholism and Smoking," Journal of Studies on Alcohol, 51(2):130-135.

Douglas, S. (1998). "The Duration of the Smoking Habit," Economic Inquiry 36(1):49-64.

Edwards, G., E. J. Marshall, and C. C. H. Cook (1997). The Treatment of Drinking Problems: A Guide for the Helping Professions. Cambridge, U.K.: Cambridge University Press.

Evans, W., and M. Farrelly (1998). "The Compensating Behavior of Smokers: Taxes, Tar and Nicotine," Rand Journal of Economics 29(3):578-595.

Fink, A., M. C. Tsai, R. D. Hayes, A. A. Moore, S. C. Morton, K. Spritzer, and J. C. Beck (2002). "Comparing the Alcohol-Related Problems Survey (ARPS) to Traditional Alcohol Screening Measures in Elderly Outpatients," Archives of Gerontology and Geriatrics, 34(1): $55-78$.

Flegal, K., R. Troiano, E. Pamuk, et al. (1995). "The Influence of Smoking Cessation on the Prevalence of Overweight in the United States," New England Journal of Medicine 333(18):1165-1170.

Goldbaum, D. (2000). "Life Cycle Consumption of a Harmful and Addictive Good," Economic Inquiry 38(3):458-469.

Gruber, J., and B. Köszegi (2001). "Is Addiction 'Rational'? Theory and Evidence," Quarterly Journal of Economics, 116(4):1261-1303.

Hearne, R. A. Connolly, and J. Sheehan (2002). "Alcohol Abuse: Prevalence and Detection in a General Hospital," Journal of the Royal Society of Medicine, 95(2):84-87.

Henningfield, J. E., R. Clayton, and W. Pollin (1990). "Involvement of Tobacco in Alcoholism and Illicit Drug Use," British Journal of Addiction, 85(2):279-291.

Johnson, K. A., and K. M. Jennison (1992). "The Drinking-Smoking Syndrome and Social Context," International Journal of Addiction, 27(7):749-792.

Jones, A. (1994). "Health, Addiction, Social Interactions and the Decision to Quit Smoking," Journal of Health Economics, 13:93-110.

Juster, F., and R. Suzman (1995). "An Overview of the Health and Retirement Study," Journal of Human Resources, 30(0), Suppl. 1995:S7-S56. 
Kandel, D. B. (1975). "Stages in Adolescent Involvement in Drug Use," Science 190(4217): 912-914.

Klesges, R. C., L. M. Klesges, and A. W. Meyers (1991). "Relationship of Smoking Status, Energy Balance, and Body Weight: Analysis of the Second Health and Nutrition Examination Survey," Journal of Consulting Clinical Psychology, 59:899-905.

McClure, J. B., D. W. Wetter, C. de Moor, P. M. Cinciripini, and E. R. Gritz (2002). "The Relation Between Alcohol Consumption and Smoking Abstinence: Results from the Working Well Trial," Addictive Behaviors, 27(3):367-379.

Miller, N. S., and M. S. Gold (1998). "Comorbid Cigarette and Alcohol Addiction: Epidemiology and Treatment," Journal of Addictive Diseases, 17(1):55-66.

Miller, W. R., K. E. Hendrick, and C. A. Taylor (1983). "Addictive Behaviors and Life Problems Before and After Behavioral Treatment of Problem Drinkers," Addictive Behaviors, 8:403-412.

Moffat, R. J., and S. G. Owens (1991). "Cessation from Cigarette Smoking: Change in Body Weight, Body Composition, Resting Metabolism, and Energy Consumption," Metabolism, 40:465-470.

Moffit, R., J. Fitzgerald, and P. Gottschalk (1999). "Sample Attrition Panel Data: The Role of Selection on Observables," Annales d'Economie et de Statistique 0(55-56):129-152.

Ostbye, T., D. H. Taylor, and S. H. Jung (2002a). "A Longitudinal Study of the Effects of Tobacco Smoking and Other Modifiable Risk Factors on Ill Health in Middle-Aged and Old Americans: Results from the Health and Retirement Study and Asset and Health Dynamics among the Oldest Old survey," Preventive Medicine, 34(3):334-345.

Ostbye, T., D. H. Taylor, Jr., K. M. Krause, and L. Van Scoyoc (2002b). "The Role of Smoking and Other Modifiable Lifestyle Risk Factors in Maintaining and Restoring Lower Body Mobility in Middle-Aged and Older Americans: Results from the HRS and AHEAD," Journal of the American Geriatrics Society, 50(4):691-699.

Perreira, K., and F. A. Sloan (2001). "Life Events and Alcohol Consumption Among Mature Adults: A Longitudinal Analysis," Journal of Studies on Alcohol, 501-507.

Pirie, P. L., D. M. Murray, and R. V. Luepker (1991). "Gender Differences in Cigarette Smoking and Quitting in a Cohort of Young Adults," American Journal of Public Health 81(3):324-327.

Rigotti, N. (1999). "Treatment Options for the Weight-Conscious Smoker," Archives of Internal Medicine, 159(11):1169-1171.

Rosengren, A., L. Wilhelmsen, and H. Wedel (1983). "Separate and Combined Effects of Smoking and Alcohol Abuse in Middle-Aged Men," Acta Medica Scandinavica, 223:111118.

Sloan, F. A., V. K. Smith, and D. Taylor (2003). Parsing the Smoking Puzzle: Information, Risk Perception, and Choice. Cambridge, Mass.: Harvard University Press.

Smith, V. K., D. H. Taylor, and F. A. Sloan (2001). "Longevity Expectations and Death: Can People Predict Their Own Demise?" American Economic Review 91(4):1126-1134.

Taylor, D. H. Jr, and T. Osbye (2001). "The Effect of Middle- and Old-Age Body Mass Index on Short-Term Mortality in Older People," Joumal of the American Geriatrics Society, 49(10):1319-1326. 
Taylor I. J., and B. J. Taylor (1984). "Double Diagnosis: Double Dilemma. The Polyaddiction: Alcoholism, Substance Abuse, Smoking, Gambling," Journal of Clinical Psychiatry 45(12):9-13.

U.S. Department of Health and Human Services (1990). "Health Benefits of Smoking Cessation: A Report of the Surgeon General." Rockville, Md.: Office of the Surgeon General. DHHS publication no. (CDC) 90 .

U.S. Department of Health and Human Services (2001). "Women and Smoking: A Report of the Surgeon General." Rockville, Md.: Office of the Surgeon General.

Wagenaar, A. (2000). "Alcohol Policies in the United States: Highlights from the 50 States," Alcohol Epidemiology Program, Minneapolis, University of Minnesota.

Wee, C. C., N. A. Rigotti, R. B. Davis, and R. S. Phillips (2001). "Relationship Between Smoking and Weight Control Efforts Among Adults in the United States," Archives of Internal Medicine, 161(4):546-550.

Williamson, D. F., J. Madans, R. F. Anda, et al. (1991). "Smoking Cessation and Severity of Weight Gain in a National Cohort," New England Journal of Medicine, 324:739-745.

Ziliak, J., and T. Kniesner (1998). "The Importance of Sample Attrition in Life Cycle Labor Supply Estimation," Journal of Human Resources, XXXIII(2):507-530. 